\title{
Effects of Albinism on Pseudomonas putida Infection on Convict Cichlid (Cichlasoma nigrofasciatum)
}

\author{
Şevki KAYIŞ $^{1^{*}} \quad$ Akif ER $^{1} \quad$ Zeynep Zehra KAÇAR ${ }^{1}$ \\ ${ }^{1}$ Recep Tayyip Erdoğan Üniversity, Faculty of Fisheries Sciences, 53100/Rize, Türkiye.
}

\begin{abstract}
In the present study, naturally infected albino convict cichlids (Cichlasoma nigrofasciatum) were examined bacteriologically. The result of the examination Puseudomonas putida was isolated from the fish. After this result, comparing the difference of this infection in normal and albino fish was aimed. So, the challenge test trial system for this purpose was settled. Normal and albino fish were infected with stocked bacteria, and the results were observed. At the end of the experiment, all albino fish were observed to have died due to infection. Whereas deaths were not observed in the normal fish. As a result, albino fish (Cichlasoma nigrofasciatum) were found to be more sensitive to Puseudomonas putida infection than normal fish.
\end{abstract}

Keywords: Fish, albinism, bacteria, mortality

\section{Convit Cichlid (Cichlasoma nigrofasciatum)'de Pseudomonas putida Enfeksiyonu Üzerine Albinism'in Etkisi}

Öz: Sunulan bu çalışmada doğal olarak enfekte olmuş çiklit (Cichlasoma nigrofasciatum) balıkları bakteriyolojik olarak incelenmisstir. Bakteriyolojik muayene sonrası balıkardan Puseudomonas putida bakterisi izole edilmiștir. Bu sonuçlar sonrası normal ve albino çiklit balıklarının bu bakteriye karșl hassasiyetinin karşılaş̧tırlması amaçlanmıştır. Bu yüzden, bir deneme düzeneği hazırlanmıştır. Normal ve albino balıklar bu bakteri ile enfekte edilmiş ve sonuçlat takip edilmiştir. Deneme sonucunda bütün albino balıkların öldüğü, normal ballklarda ise ölüm olmadı̆̆ gözlemlenmiştir. Sonuç olarak albino balıkların (Cichlasoma nigrofasciatum) normal balıklara göre Puseudomonas putida enfeksiyonuna daha hassas olduğu ortaya konulmuştur.

Anahtar sözcükler: Balık, albinism, bakteri, ölüm

\section{GíRiş}

Fish diseases are one of the important issues due to its adverse effects in reared and wild fish population. Diseases in fishes caused by many reasons such as; virulence of pathogens (bacteria, parasites, viruses and fungus), water quality parameters (oxygen, $\mathrm{pH}$, temperature, hardness, ammonia, etc.), age of the fish and nutritional changes (Noga, 2010). The occurrence of parasites (Koyuncu and Donmez, 2006; Kayis et al., 2009; Er and Kayis, 2015), viruses and bacteria (Oztürk and Altinok, 2014) on consumed, wild and ornamental fish species have been documented in different papers. Also, nutritional problems of fish can cause serious damages, particularly on reared fish species.

However, genetic factors in fish disorders generally less common studied by researchers (Ferguson and Danzmann, 1998). Morphological changes and albinism are the most encountered genetic disorders in fishes. National Organization for Albinism and Hypopigmentation (NOAH), satated that albinism is an inherited genetic condition that reduces the amount of melanin pigment formed in the skin, hair and/or eyes. Common fish albinisms are germane mutations of the tyrosinase family of genes, where the skin of albinos lack melanin and eye development is affected (Wang et al., 2007).

Apart from the difference in appearance and growth rates or performance, the difference in terms of health resistance has not been studied much. So, the present study aimed that the different effects of Puseudomonas putida infection on normal and albino convict cichlid (Cichlasoma nigrofasciatum) individuals.

\section{MATERIAL and METHODS}

Five moribund albino cichlids (Cichlasoma nigrofasciatum), become sick after a natural infection, were sampled from aquarium units in Recep Tayyip Erdoğan University, Faculty of Fisheries Sciences. Fish were examined for bacteriologycal. The body surface of fish was swabbed with $70 \%$ ethyl alcohol. The liver, trunk kidney, and spleen were aseptically streaked on tryptic soy agar (TSA). The medium, incubated at $22^{\circ} \mathrm{C}$ temperature and then pure cultured colonies was biochemically characterized by API 20NE (API profile number: 0142457) (Biomerieux, Marcy l'Etoile, France). Before the biochemical application cytochrome oxidase, Gram stain, motility tests and glutamate starch phenol red agar (GSP) were used and bacteria named as Puseudomonas putida.

Antibiotic susceptibility of bacteria was determined by the agar diffusion method on Muller Hinton Agar using $9 \mathrm{~mm}$ diameter commercial discs (Bioanalyse, Ankara, Turkey), contained the following antibiotics (mg/disc): ampicillin 10, Enrofloxacin 5, streptomycin 10, oxolinic acid 2, oxytetracycline 30, sulphamethoxazole 25, Florfenicol 30 (NCCLS, 2002). Isolates were considered susceptible if the inhibition zone equaled or exceeded $17 \mathrm{~mm}$ for ampicillin, $15 \mathrm{~mm}$ for Enrofloxacin, streptomycin, oxytetracycline, florfenikol, and $20 \mathrm{~mm}$ for oxolinic acid and $16 \mathrm{~mm}$ for sulphamethoxazole.

Antibiotic susceptibility of bacteria was determined by the agar diffusion method on Muller Hinton Agar using $9 \mathrm{~mm}$ diameter commercial discs (Bioanalyse, Ankara, Turkey), contained the following antibiotics (mg/disc): ampicillin 10, Enrofloxacin 5, streptomycin 10, oxolinic acid 2, oxytetracycline 30, sulphamethoxazole 25, Florfenicol 30 (NCCLS, 2002). Isolates were considered susceptible if the inhibition zone equaled or exceeded $17 \mathrm{~mm}$ for ampicillin, $15 \mathrm{~mm}$ for Enrofloxacin, streptomycin, oxytetracycline, florfenikol, and $20 \mathrm{~mm}$ for oxolinic acid and $16 \mathrm{~mm}$ for sulphamethoxazole.

\section{RESULTS}

A bacterium isolated from trunk kidney, liver and spleen of moribund fish characterized as cytochrom oxidase positive, Gram negative and motile Puseudomonas putida. Large red/pink colonies were observed in GSP agar. $P$. putida isolated from fish in the present study was resistant to all antibiotics in the used except for Enrofloxacin. 
Mass mortalities occurred in albino convict cichlids and mortality reached $100 \%$ within two weeks. No fish died in control groups of albino/normal convict cichlids and infective normal fish with $P$. putida. Externally, affected albino fish had advanced bilateral exophthalmia and internally clinical signs included enlarged spleen and pale liver.

\section{DISCUSSION}

Although Puseudomonas putida has been associated with human, particularly in children (Bouallegue et al., 2004), the bacteria isolated only three fish species from ayu (Plecoglossus altivelis altivelis) and yellowtail (Seriola quinqueradiata) in Japan (Kusuda and Toyoshima, 1976; Muroga, 1990; Wakabayashi et al., 1996) and rainbow trout (Oncorhynchus mykiss) (Altinok et al, 2006) in Turkey. These fish species are consumed fish, particularly rainbow trout is a common fish species in the cold water systems. However, Cichlasoma nigrofasciatum is very common ornamental fish species in all over the world. This study firstly demonstrated that $P$. putida causes important mortality in ornamental fish (although the albino) at high water temperatures.

Albinism can cause some anomalies in different organisms such as sunburn, eye damages and hypoplasia and also it has been linked in rare cases with systemic diseases. The most common is Hermansky-Pudlak Syndrome (HPS) in humans. Albinism is a set of inherited disorders that result from the inability of the body to produce melanin pigment. Melanin is a dark pigment that protects tissues from ultraviolet radiation. Fabacher et al. (1999) stated that no difference in the number of albino and pigmented medaka (Oryzias latipes) that died during the exposure period. However, hypoplasia is under development or incomplete development of a tissue or organ. Because of less development or incomplete of immune system in albino species may be caused mortality in infected fish.

Comparison of growth rates or performance of normal and albino rainbow trout (Oncorhynchus mykiss) and channel catfish (Ictalurus punctatus) were reported in different study (Okumus et al., 2001; Bondari, 1984). Statistical analysis of the final weight values of trout showed that in the study only the normally pigmented fish exhibited significantly higher growth. Similarly the other study demonstrated that fish growth, survival and production activities were significantly higher in normal catfish. This information shows that albino fish generally can not provide the important values in aquaculture.

\section{CONCLUSION}

The present study demonstrated that the infection caused by Pseudomonas putida in albino convict cichlids. However, we think that albino fish must be studying in the future all possibilities (causative factors for diseases) taking into account such as; water quality parameters, genetic factors, immune system interactions, blood values, effects of different bacteria and different fish species.

\section{REFERENCES}

Altinok I., Kayis S. and Capkin E., (2006). Pseudumonas putida infection in rainbow trout. Aquaculture, 261, 850-855.

Bondari K., (1984). Comparative performance of albino and normally pigmented channel catfish in tanks, cages, and ponds. Aquaculture, 37 (4), 293-301.
Bouallegue O., Mzoughi R., Weill FX., Mahdhaoui N., Salem BY. Sboui H., Grimont F. and Grimont PA., (2004). Outbreak of Pseudomonas putida bacteraemia in a neonatal intensive care unit. J. Hosp. Infect., 57, 88-91.

Er A. and Kayis S., (2015). Intensity and prevalence of some crustacean fish parasites in Turkey and their molecular identification, Turkish Journal of Zoology, 39, 1142-1150.

Fabacher DL., Little EE. and Ostrander GK., (1999). Tolerance of an albino fish to ultraviolet-B radiation, Environ Sci Pollut Res Int., 6(2), 69-71.

Ferguson MM. and Danzmann RG., (1998). Genetic disorders, in fish diseases and disorders, Volume 2:Non-Infectious disorders (eds JF leatherland and PTK Woo).

Kayiş S., Capkin E., Balta F. and Altinok I., (2009). Bacteria in rainbow trout (Oncorhynchus mykiss) in the Southern Black Sea Region of Turkey - A Survey. The Israeli Journal of Aquaculture Bamidgeh 61(4), 339-344.

Koyuncu CE. and Dönmez AE., (2006). Mersin Bölgesinde yetiştiriciliği yapılan bazı akvaryum balıkları (POECILIDAE)'nda rastlanılan Lernea cyprinaceae (Linnaeus, 1758) Enfeksiyonu. E.U. Journal of Fisheries \& Aquatic Sciences, 23(1/2), 265-267.

Kusuda R. and Toyoshima T., (1976). Characteristics of a pathogenic Pseudomonas isolated from cultured yellowtail. Fish Pathol., 1, 133-139.

Muroga K., (1990). Bacterial infections in cultured fishes in Japan. In: Hirano, R., Hanyu, I. (Eds.), The Second Asian Fisheries Forum, Manila. Asian Fisheries Society, 963-966.

Noga EJ., (2010). Fish disease diagnosis and treatment. $2^{\text {nd }}$ Edition,

Okumus, I., Degirmenci, A., Bascinar, N. and Celikkale, M. S. (2001). Comparative, Approximate Biochemical Composition and Consumer preference of Albino and Normally pigmented varieties of Rainbow Trout (Onc orhynchus mykiss). Turkish Journal of Fisheries and Aquatic Sciences, 1, 23-28.

Öztürk RÇ. and Altinok İ., (2014). Bacterial and viral fish diseases In Turkey, Turk J Fish Aquat Sc. 14, 275-297.

Shinn A.P., Hansen H., Olstad K., Bachmann L. and Bakke TA. (2004). The use of morphometric characters to discriminate specimens of laboratory-reared and wild populations of Gyrodactylus salaris and G. thymalli (Monogenea). Folia Parasitol., 51, 239252 .

Wakabayashi H., Sawada K., Ninomiya K. and Nishimori E., (1996). Bacterial hemorrhagic ascites of ayu caused by Pseudomonas sp. Fish Pathol., 31, 239-240.

Wang J., Hou L., Zhang R., Zhao X., Jiang L., Sun W., An J. And Li X., (2007). The tyrosinase gene family and albinism in fish. Chinese Journal of Oceanology and Limnology, 25(2), 191-198.

Winfree RA., (1989). Tropical fish: Their production and marketing in the United States. World Aquaculture, 20, 24-30.

Received date: 13.11 .2017

Accepted date: 27.11 .2017

*Corresponding author's:

Doç. Dr. Şevki KAYIŞ

Recep Tayyip Erdoğan University, Faculty of Fisheries Sciences 53100 Rize, Turkey.

E-mail: aquasevki@msn.com 